\title{
KURANGNYA ASUPAN ENERGI DAN LEMAK YANG BERHUBUNGAN DENGAN STATUS GIZI KURANG PADA BALITA USIA 25-60 BULAN
}

\author{
Ardian Nurdianto Firman ${ }^{1}$, Trias Mahmudiono \\ 1,2 Departemen Gizi Kesehatan, \\ Fakultas Kesehatan Masyarakat'Universitas Airlangga \\ Alamat Korespondensi: Ardian Nurdianto Firman \\ E-mail: ardiannurdianto@gmail.com
}

\begin{abstract}
The prevalence of underweight in 2010 to 2013 has increased percentage by $17.9 \%$ to $19.6 \%$. Household food security and food intake were factors that can affect nutritional status of children. The aim of the study was to analize the relationship between status of household food security, energy and fat intake with nutrititional status of children. This was a cross sectional study with 40 samples selected using simple random sampling technique. Subject in this study was the fisherman family whose toddlers age 25-60 months. The data were collected by interview using questionaires, and were analyzed using linier regression and spearmen test. The result showed that 55\% of households were facing food insecurity and $45 \%$ households were food insecure with severe hunger. Nutritional status of children (72,5\%) were normal and (27,50\%) wereunderweight. Energy intake has a significant relationship with nutritional status of children $(p=0,007)$ and fat $(p=0,03)$.
\end{abstract}

Keywords: household food security, nutritional status, intake energy and fat

\begin{abstract}
ABSTRAK
Prevalensi masalah gizi kurang pada tahun 2010 ke tahun 2013 mengalami peningkatan persentase sebesar 17,9\% menjadi 19,6\%. ketahanan pangan rumah tangga dan asupan makanan adalah faktor yang mempengaruhi status gizi balita. Tujuan penelitian adalah menganalisis hubungan antara ketahanan pangan rumah tangga, asupan energi dan lemak dengan status gizi balita $(\mathrm{BB} / \mathrm{U})$. Penelitian menggunakan desain cross sectional dengan besar sampel 40 yang dipilih menggunakan simple random sampling. Subyek dalam penelitian adalah keluarga nelayan yang memiliki balita usia 25-60 bulan. Pengumpulan data dilakukan dengan wawancara menggunakan kuesioner. Uji Statistik yang digunakan adalah uji regresi linier dan spearmen.Hasil menunjukkan rumah tangga rawan pangan dengan kelaparan (55\%) dan rumah tangga rawan pangan dengan kelaparan parah $(45 \%)$. Status gizi balita baik (72,5\%) dan gizi kurang (27,50\%). Ada hubungan status gizi balita dengan energi $(p=0,007)$ dan lemak $(p=0,03)$. Asupan energi dan lemak memiliki hubungan signifikan dengan status gizi balita
\end{abstract}

Kata kunci: status ketahanan pangan, status gizi balita, asupan energi, dan lemak.

\section{PENDAHULUAN}

Kesehatan pangan rumah tangga merupakan salah satu faktor yang dapat mempengaruhi status gizi balita. Ketahanan pangan tingkat rumah tangga adalah kemampuan sebuah keluarga untuk memenuhi kebutuhan pangan dan menjamin kecukupan asupan makanan bagi setiap anggota keluarga. Secara luas ketahanan dapat diartikan sebagai terjaminnya akses pangan bagi setiap individu yang bertujuan untuk hidup sehat (Saliem dan Ariani, 2016). Status gizi adalah keluaran dari ketahanan pangan rumah tangga. Kemampuan rumah tangga untuk menyediakan pangan yang dikonsumsi dapat mempengaruhi status gizi pada masing-masing anggota keluarga (Yuliana, dkk. 2013).

Nelayan merupakan salah satu golongan yang beresiko terjadi rawan pangan yang disebabkan oleh keterbatasan aset, kemampuan modal yang kurang, posisi menawar, dan akses pasar (Sari, 2011). Keluarga nelayan adalah keluarga yang identik dengan kemiskinan dan rawan pangan.

Angka kemiskinan di Indonesia masih tinggi. Pada tahun 2016 penduduk 
miskin di Indonesia sebesar 28,01 juta orang atau sekitar 10,86\% (BPS Kota Surabaya, 2016). Jawa Timur merupakan wilayah yang memiliki angka kemisikinan cukup tinggi sebesar 4,7 juta jiwa. Jumlah penduduk miskin Surabaya 140.230 jiwa (BPS Kota Surabaya, 2016). Berdasarkan data BPS Kota Surabaya jumlah keluarga miskin di Kelurahan Sukolilo Baru sebesar 120 keluarga yang sebagian besar bermata pencarian sebagai nelayan.

Pendapatan atau penghasilan dalam rumah tangga merupakan salah satu faktor yang dapat mempengaruhi konsumsi pangan di dalam rumah tangga (Rachman, 2016). Pendapatan nelayan diperoleh dari banyaknya hasil penangkapan ikan sehingga dapat mempengaruhi kebutuhan pangan maupun non pangan (Widyaningsih dan Muflikhati, 2015).

Konsumsi pangan rumah tangga dapat dipengaruhi oleh beberapa faktor seperti jumlah pendapatan rumah tangga dan jumlah anggota keluarga. Pendapatan yang diperoleh nelayan tergantung pada hasil tangkapan ikan. Selain pendapatan faktor yang mempengaruhi konsumsi pangan pada rumah tangga adalah jumlah anggota keluarga dan tingkat pendidikan (Ningsih, 2014).

Status gizi adalah salah satu faktor yang menentukan kualitas tumbuh kembang individu. Status gizi di masyarakat sering menggambarkan masalah gizi pada kelompok balita. Masalah gizi biasanya disebabkan oleh kurangnya asupan gizi, kurangnya pengetahuan mengenai gizi seimbang, dan kemiskinan (Putri dkk, 2016).

Masalah gizi kurang merupakan masalah yang paling sering ditemui setiap tahun di Indonesia. Prevalensi masalah gizi kurang pada tahun 2010 ke tahun 2013 mengalami peningkatan prosentase sebesar 17,9\% menjadi 19,6\% (Riskesdas, 2013). Provinsi jawa timur salah satu wilayah yang mengalami peningkatan masalah gizi kurang sebesar $12,1 \%$ dan salah satunya terjadi di Kota Surabaya. Kasus balita gizi kurang sebanyak 626 kasus gizi kurang yang perlu perhatian pemerintah Kota Surabaya. Berdasar data dari Puskesmas Kenjeran masalah gizi kurang pada balita sebesar 128 kasus di wilayah Kecamatan Bulak, 25 kasus terjadi di Kelurahan Sukolilo Baru.

Asupan makronutrien dan energi berkaitan dengan status gizi. Energi diperoleh melalui konsumsi makronutrien berupa karbohidrat, protein, dan lemak (Regar dan Sekartini, 2014). Usia balita memiliki kebutuhan asupan makronutrien untuk pertumbuhan dan status gizi balita yang baik.

Berdasarkan uraian di atas, peneliti tertarik untuk mengkaji lebih lanjut mengenai hubungan ketahanan pangan rumah tangga nelayan dan asupan makronutrien dengan status gizi balita $(\mathrm{BB} / \mathrm{U})$ usia 25-60 bulan. Tujuan penelitian ini adalah untuk mengetahui hubungan ketahanan pangan rumah tangga nelayan dan asupan makronutrien dengan status gizi balita $(\mathrm{BB} / \mathrm{U})$ di Kelurahan Sukolilo Baru Kecamatan Bulak Kota Surabaya.

\section{METODE PENELITIAN}

Penelitian ini merupakan penelitian analitik observasional dengan menggunakan desain cross sectional. Penelitian dilakukan di Kelurahan Sukolilo Baru, Kecamatan Bulak, Kota Surabaya pada bulan Agustus 2017. Subyek dalam penelitian adalah keluarga nelayan yang memiliki balita di Kelurahan Sukolilo Baru. Besar sampel sebanyak 40 dengan cara pemilihan sampel secara acak sederhana (simple random sampling).

Pengumpulan data pada penelitian ini dilakukan dengan wawancara menggunakan kuesioner dan food recall $2 \times 24$ jam pada balita tidak berurutan pada hari yang sama kemudian diolah dengan software nutrisurvey untuk melakukan pengelompokkan asupan termasuk kategori defisit atau normal. Status gizi balita menggunakan indeks berat badan menurut umur. 
Wawancara dilakukan kepada orang tua balita untuk mengetahui status ketahanan pangan. Kuesioner yang digunakan yaitu United States-Household Food Security Survey Mobile (USHFSSM) dengan 16 pertanyaan. Skor yang dihasilkan akan digunakan untuk menentukan status ketahanan pangan pada rumah tangga. Kategori skor status ketahanan pangan rumah tangga yaitu 0-2 tahan pangan, 3-7 rawan pangan tanpa kelaparan, 8-12 rawan pangan dengan kelaparan, dan 13-18 rawan pangan dengan kelaparan parah.

Variabel dependent pada penelitian adalah status gizi balita berat badan menurut usia $(\mathrm{BB} / \mathrm{U})$, sedangkan variabel independent adalah ketahanan pangan rumah tangga, asupan energi, karbohidrat, lemak, dan protein. Kategori untuk asupan dibagi menjadi dua yaitu defisit dan normal.

Analisis data terdiri dari analisis univariat dan analisis bivariat. Analisis univariat untuk menggambarkan distribusi frekuensi dari variabel yang diteliti. Uji statistika yang digunakan adalah uji regresi linier dan uji spearmen. Uji statistik regresi linier digunakan untuk mengetahui keterkaitan antara variabel independent dengan status gizi balita $\mathrm{BB} / \mathrm{U}$ sedangkan uji spearmen digunakan untuk mengetahui hubungan variabel ketahanan pangan dengan asupan energi dan lemak.

\section{HASIL}

Karakterisitik responden dalam penelitian yaitu usia kepala keluarga, pendidikan terakhir, pendapatan keluarga, jumlah anggota keluarga, status ketahanan pangan rumah tangga, status gizi balita, dan asupan energi, karbohidrat, lemak, serta protein pada balita dapat dilihat pada Tabel 1. Data usia kepala keluarga ditunjukkan pada Tabel 1, sebagian besar memiliki usia sangat produktif (95\%). Rata-rata kepala keluarga berusia 34 tahun.Tidak ada kepala keluarga yang mempunyai usia tidak produktif (0-14 tahun) dan kurang produktif (65 tahun).

Sebagian besar pendidikan terakhir kepala keluarga sebanyak 19 orang (47,5\%) kepala keluarga tamat SMP, dan paling sedikit tamat SMA sebanyak 3 orang $(7,50 \%)$. Berdasarkan data tersebut sebagian besar kepala keluarga pendidikan terakhir SD dan SMP. Tidak ada kepala keluarga yang tidak sekolah, tidak tamat $\mathrm{SD}$, dan tamat perguruan tinggi.

Tabel 1. Karakteristik Responden

\begin{tabular}{llcc}
\hline & Variabel & n & \% \\
\hline Usia Kepala Keluarga & 15-49 tahun & 38 & 95 \\
& 50-64 tahun & 2 & 5 \\
Pendidikan Terakhir & Tamat SD & 18 & 45 \\
& Tamat SMP & 19 & 47 \\
& Tamat SMA & 3 & 7,5 \\
& Kecil & 19 & 47,5 \\
\multirow{5}{*}{ Tumlah Anggota Keluarga } & Sedang & 18 & 45 \\
& Besar & 3 & 7,5 \\
Tingkat asupan energi & Normal & 27 & 67,5 \\
& Defisit & 13 & 32,5 \\
& Normal & 28 & 70 \\
& Defisit & 12 & 30 \\
\hline
\end{tabular}




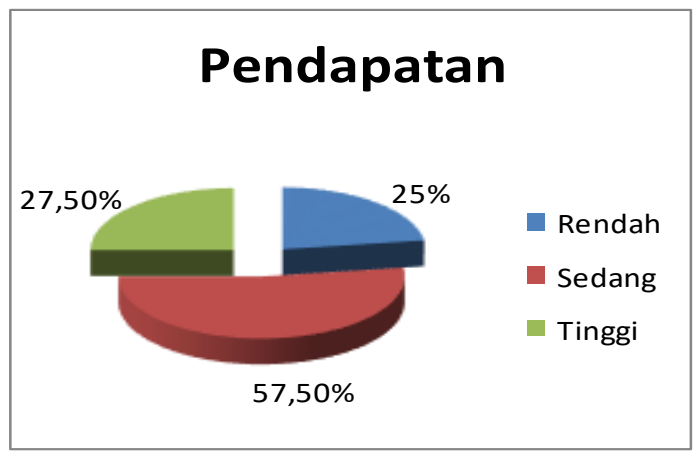

Gambar 1. Persentase Pendapatan

Pendapatan keluarga per hari ratarata berkisar Rp. $100.000,00$ sampai dengan Rp. 550.000,00 dengan rata-rata Rp. 349.500,00. Responden yang memiliki pendapatan kategori rendah Rp. 100.000,00 sampai dengan Rp. 280.000, responden yang memiliki pendapatan kategori sedang Rp. 290.000,00 sampai dengan Rp. 390.000,00 dan responden yang memiliki pendapatan kategori tinggi Rp. 400.000,00 sampai dengan Rp. $550.000,00$ sebanyak 7 orang $(27,5 \%)$.

Kategori jumlah anggota keluarga responden yang dibagi menjadi tiga kategori yaitu kecil, sedang dan besar. Sebagian besar yang memiliki anggota keluarga kecil sebanyak 19 orang (47,5\%). Seperti di tunjukkan Tabel 1

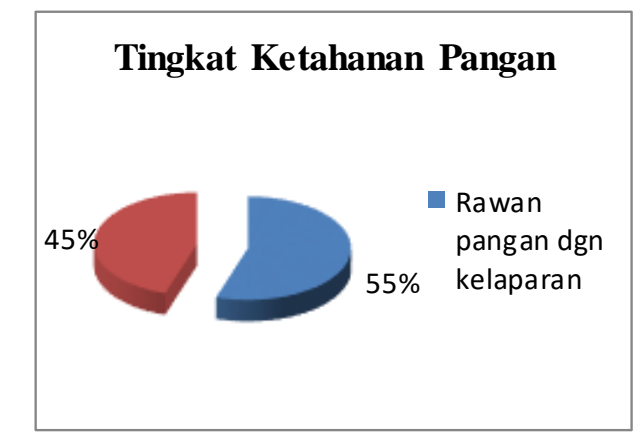

Gambar 2. Persentase Tingkat Ketahanan Pangan Rumah Tangga

Status ketahanan pangan rumah tangga diperoleh dari hasil wawancara kepada responden untuk mengetahui status ketahanan pangan rumah tangga.

Hasil wawancara menunjukkan sebagian besar rumah tangga nelayan di Kelurahan Sukolilo Baru termasuk kategori rawan pangan. Rawan pangan dengan kelaparan sebanyak 22 rumah tangga $(55 \%)$ dan rawan pangan dengan kelaparan parah berjumlah 18 rumah tangga (45\%).

Balita pada penelitian ini merupakan balita dari responden. Status gizi balita diperoleh melalui pengukuran antropometri yaitu menimbang berat badan. Indeks status gizi yang digunakan adalah berat badan menurut umur $(\mathrm{BB} / \mathrm{U})$. Hasil yang diperoleh dari pengukuran berat badan balita menunjukkan sebagian besar memiliki status gizi baik sebanyak 29 orang $(72,50 \%)$ drprti yang ditunjukkan Gambar 3.

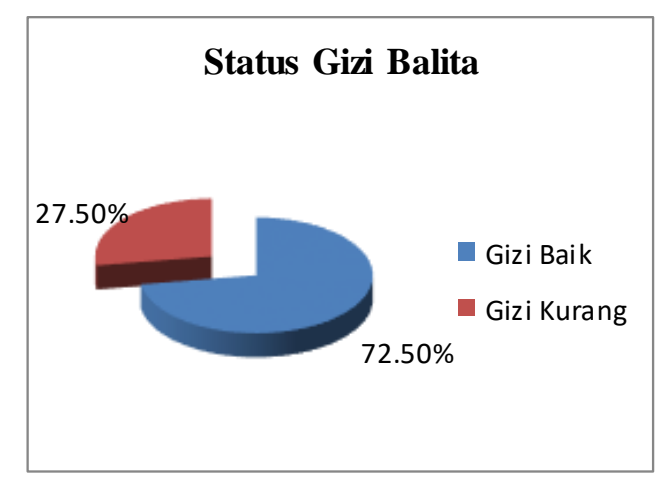

Gambar 3. Persentase Starus Gizi Balita

Variabel yang berhubungan dengan status gizi pada penelitian ini adalah asupan energi dan zat gizi makronutrien. Asupan energi, karbohidrat, lemak, dan protein diperoleh dari recall $2 \times 24$ jam. Recall tidak dilakukan secara berurutan pada hari yang sama.

Gambar 4 menampilkan grafik perbandingan asupan energi dengan status gizi balita yaitu gizi baik dan gizi kurang. Hasil menunjukkan balita yang memiliki status gizi kurang sebanyak 11 orang. 9 orang mengalami defisit asupan energi dan 2 orang asupan energi yang normal. Berdasarkan data hasil penelitian maka dapat disimpulkan bahwa balita yang memiliki status gizi kurang beresiko defisit asupan energi.

Hasil penelitian menunjukkan balita yang memiliki status gizi kurang dan defisit asupan lemak sebanyak 7 orang sedangkan 4 orang mempunyai asupan 
lemak yang normal. Balita yang memiliki status gizi baik dan defisit asupan lemak sebanyak 5 orang dan 24 orang asupanlemak normal. Berdasarkan data hasil penelitian maka dapat disimpulkan bahwa balita yang memiliki status gizi kurang beresiko defisit asupan lemak. Grafik dapat dilihat pada gambar nomor 5 . Hasil uji statistika pada penelitian menggunakan uji regresi linier antara variabel dependent dengan independent dapat dilihat pada Tabel 2. Variabel dependent adalah status gizi dan independent yaitu asupan karbohidrat, lemak, protein, dan status ketahanan pangan rumah tangga nelayan.

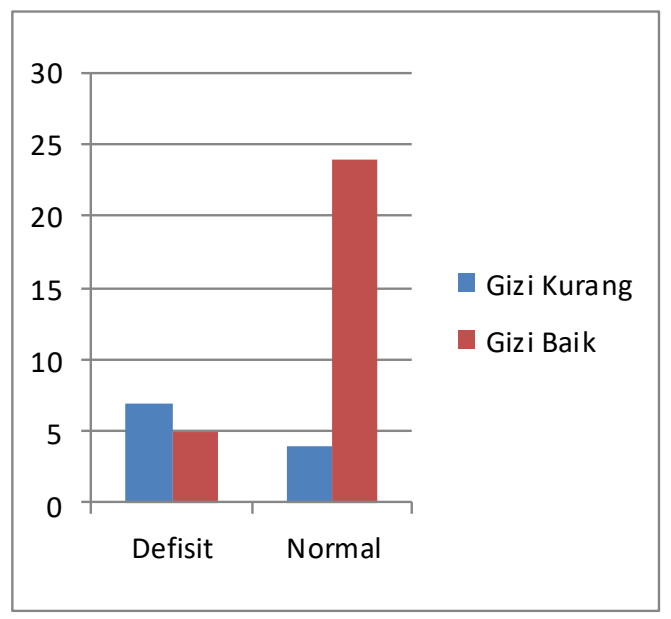

Gambar 4. Grafik Kategori Energi

Hasil uji regresi linier pada tabel 2 memperlihatkan asupan energi terhadap status gizi balita memiliki p-value sebesar 0,007 ( $p=0,007$ kurang dari $\alpha=0,05$ ), yang artinya terdapat hubungan yang signifikan antara asupanenergi dengan status gizi balita $(\mathrm{BB} / \mathrm{U})$. Asupan karbohidrat terhadap status gizi balita memiliki p-value sebesar 0,087 ( $p=0,087$ lebih dari $\alpha=0,05)$, yang artinya tidak ada hubungan yang signifikan antara asupan karbohidrat dengan status gizi balita $(\mathrm{BB} / \mathrm{U})$. Asupan lemak terhadap status gizi balita memiliki $\mathrm{p}$-value sebesar $0,030(p=0,030$ kurang dari $\alpha=0,05$ ), yang artinya ada hubungan yang signifikan antara asupan lemak dengan status gizi balita $(\mathrm{BB} / \mathrm{U})$. Asupan protein terhadap status gizi balita memiliki $p$-value sebesar 0,423 ( $p=0,423$ lebih dari $\alpha=0,05)$, yang artinya tidak ada hubungan yang signifikan antara asupan protein dengan status gizi balita $(\mathrm{BB} / \mathrm{U})$. Status ketahanan pangan terhadap status gizi balita memiliki $p$-value sebesar $0,758(p=0,758$ lebih dari $\alpha=0,05)$, yang artinya tidak ada hubungan yang signifikan antara status ketahanan pangan dengan status gizi balita $(\mathrm{BB} / \mathrm{U})$. Berdasarkan analisis uji regresi linier di atas dapat disimpulkan bahwa variabel yang memiliki hubungan yang kuat dengan status gizi balita adalah asupan energi dan asupan lemak sedangkan status ketahanan pangan rumah tangga tidak mempengaruhi status gizi balita berat badan menurut umur $(\mathrm{BB} / \mathrm{U})$.

Selain uji regresi linear, dilakukan uji spearmen. Tujuan untuk melakukan Uji spearmen adalah untuk mengetahui apakah ada hubungan antara asupan energi dan lemak dengan status ketahanan pangan rumah tangga. Ketahanan pangan adalah salah satu faktor tidak langsung yang dapat mempengaruhi status gizi individu. Pada hasil sebelumnya menunjukkan bahwa energi dan lemak sangat berkaitan dengan status gizi balita. Hal tersebut menunjukkan bahwa rawan pangan dapat mempengaruhi asupan energi dan lemak. Hasil uji regresi linier maka dilakukan uji statistik Spearmen. Uji statistik ini dilakukan untuk mengetahui seberapa kuat hubungan asupan energi dan lemak dengan ketahanan pangan rumah tangga. Data penelitian yang diperoleh balita yang mengalami defisit asupan lemak serta memiliki status rawan pangan dengan kelaparan yaitu sebanyak 8 balita dan yang memiliki status rawan pangan dengan kelaparan parah sebanyak 4 balita. Berdasarkan hasil data penelitian tersebut rumah tangga yang memiliki status ketahanan pangan kategori rawan pangan beresiko balita mengalami kurangnya asupan lemak. 


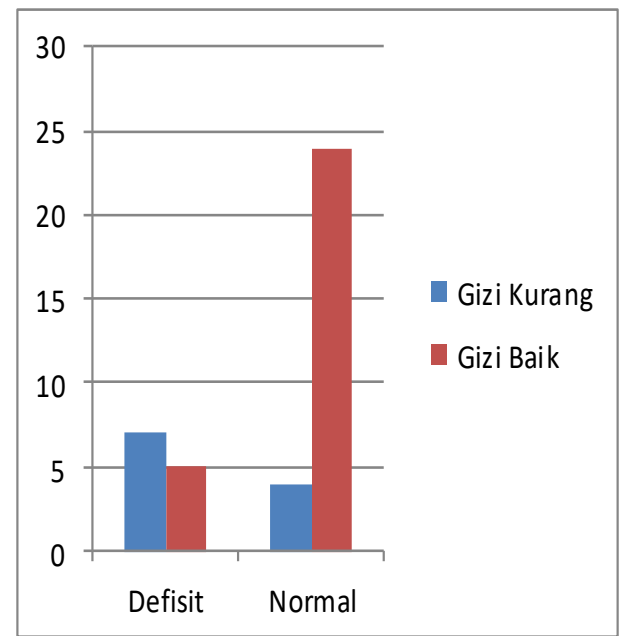

Gambar 5. Grafik Kategori Lemak

Selain itu data balita yang memiliki asupan lemak normal serta memiliki status rawan pangan dengan kelaparan s ebanyak 14 balita dan rawan pangan dengan kelaparan parah sebanyak 14 balita. Berdasarkan data yang diperoleh rumah tangga yang memiliki status rawan pangan juga memiliki resiko pada balita yang memiliki asupan energi normal.

Gambar 3 menunjukkan data balita yang mengalami defisit asupan energi serta memiliki staus rawan pangan dengan kelaparan sebanyak 6 orang dan 7 orang rawan pangan dengan kelaparan parah. Selain itu, balita yang memiliki asupan energi normal serta memiliki status rawan pangan dengan kelaparan sebanyak 16 orang dan 18 orang rawan pangan dengan kelaparan parah.

Hasil uji statistik Spearmen pada Tabel 3 didapatkan asupan energi terhadap ketahanan pangan memiliki $p$-value sebesar 0,435 ( $p=0,435$ lebih dari $\alpha 0,05)$, yang artinya tidak ada hubungan yang signifikan antara asupan energi dengan status ketahanan pangan rumah tangga. Asupan lemak terhadap ketahanan pangan memiliki $p$-value sebesar $0,435 \quad(\mathrm{p}=0,435$ lebih dari $\alpha 0,05)$, yang artinya tidak ada hubungan antara asupan lemak dengan status ketahanan pangan rumah tangga. Kedua hasil uji statistik spearmen antara status ketahanan pangan rumah tangga dengan asupan energi dan lemak menunjukkan bahwa tidak ada hubungan. Asupan energi dan lemak hanya memiliki hubungan terhadap status gizi balita.

Tabel 2. Hasil Uji Regresi Linear

\begin{tabular}{|c|c|c|c|c|}
\hline \multirow[b]{2}{*}{ Variabel } & \multirow[b]{2}{*}{$\mathbf{t}$} & \multirow[b]{2}{*}{ p-value } & \multicolumn{2}{|c|}{ Collinearity Statistics } \\
\hline & & & Tolerance & VIF \\
\hline Tingkat Asupan Energi & 2,873 & 0,007 & 0,625 & 1,601 \\
\hline Tingkat Asupan Karbohidrat & 1,765 & 0,087 & 0,675 & 1,482 \\
\hline Tingkat Asupan Lemak & 2,259 & 0,030 & 0,778 & 1,285 \\
\hline Tingkat Asupan Protein & 0,811 & 0,423 & 0,911 & 1,098 \\
\hline Tingkat Ketahanan Pangan & 0,311 & 0,758 & 0,936 & 1,068 \\
\hline
\end{tabular}


Tabel 3. Hasil Uji Spearmen

\begin{tabular}{|c|c|c|c|c|c|c|c|}
\hline \multirow{3}{*}{$\begin{array}{c}\text { Asupan } \\
\text { Gizi }\end{array}$} & \multicolumn{4}{|c|}{ Status Ketahanan Pangan } & \multirow{3}{*}{ Total } & \multirow{3}{*}{$\%$} & \multirow{3}{*}{$\begin{array}{c}\text { p- } \\
\text { value }\end{array}$} \\
\hline & \multicolumn{2}{|c|}{$\begin{array}{c}\text { Rawan Pangan } \\
\text { dengan } \\
\text { Kelaparan } \\
\end{array}$} & \multicolumn{2}{|c|}{$\begin{array}{c}\text { Rawan Pangan } \\
\text { dengan Kelaparan } \\
\text { Parah } \\
\end{array}$} & & & \\
\hline & $\mathbf{N}$ & $\%$ & $\mathbf{n}$ & $\%$ & & & \\
\hline Defisit & 6 & 15 & 7 & 85 & 13 & 100,0 & \multirow{2}{*}{0,435} \\
\hline Normal & 16 & 40 & 18 & 60 & 27 & 100,0 & \\
\hline \multicolumn{8}{|l|}{ Lemak } \\
\hline Defisit & 8 & 20 & 4 & 80 & 12 & 100,0 & \multirow{2}{*}{0,332} \\
\hline Normal & 14 & 35 & 14 & 65 & 28 & 100,0 & \\
\hline
\end{tabular}

\section{PEMBAHASAN}

Status ketahanan pangan rumah tangga pada keluarga nelayan di Kelurahan Sukolilo Baru sebagian besar termasuk kategori rawan pangan dengan kelaparan parah. Hal ini dikarenakan pendapatan yang diperoleh oleh nelayan yang tidak tetap sehingga ketersediaan pangan tidak sepenuhnya setiap hari dapat dipenuhi.

Ketahanan pangan rumah tangga merupakan kemampuan keluarga untuk menjamin kecukupan asupan makanan bagi setiap anggota keluarga sehingga dapat disebut sebagai keluarga tahan pangan (Sukandar, 2006). Pengertian ketahanan pangan rumah tangga secara luas adalah terjaminnya akses pangan bagi setiap individu untuk memenuhi kebutuhan pangan agar dapat beraktivitas dan hidup sehat (Saliem, 2016).

Pada penelitian ini menunjukkan bahwa status ketahanan pangan pada keluarga nelayan dilihat dari akses ekonomi termasuk kategori rawan pangan. Hal sesuai dengan penelitian Sukiyono (2008) yaitu ketahanan pangan rumah tangga termasuk di wilayah pesisir termasuk rawan dilihat dari salah satu indikator ketahanan pangan rumah tangga yaitu akses ekonomi keluarga terhadap pangan.

Ketahanan pangan tingkat rumah tangga nelayan sebagian besar rawan pangan. Faktor yang dapat mempengaruhi hubungan ketahanan dengan status gizi balita adalah status ekonomi (Rohaedi, 2016). Keluarga yang berasal dari kelompok sosio ekonomi yang rendah, kurang memiliki pengetahuan untuk memberikan makanan yang kaya gizi untuk membantu perkembangan anak yang optimal (Wong, 2008). Pendapatan yang diperoleh nelayan sebagian besar digunakan untuk membeli bahan non pangan yang tidak perlu dan bermanfaat untuk keluarganya (Muflikhati, 2010).

Hasil data status ketahanan pangan keluarga nelayan diperoleh melalui wawancara diketahui jumlah keluarga nelayan yang rawan pangan dengan kelaparan sebanyak 22 rumah tangga sedangkan 18 rumah tangga rawan kelaparan dengan kelaparan parah.

Hal ini sesuai dengan penelitian dari Tajerin (2011) diketahui bahwa sebagian besar rumah tangga nelayan memilikistatus ketahanan pangan rumah tangga rawan pangan. Penyebab keluarga nelayan beresiko rawan pangan karena kurangnya ketersediaan dan pemanfaatan pangan untuk dikonsumsi. Nelayan adalah salah satu yang tergolong rawan pangan yang disebabkan oleh keterbatasan aset, kemampuan modal yang kurang, dan akses ke pasar (Sari, 2013).

Hasil penelitian Yuliana (2013) yang dilakukan pada nelayan, diketahui bahwa ketahanan pangan rumah tangga nelayan termasuk kategori rawan pangan dan sebagian keluarga belum mampu memenuhi kebutuhan energi pada 
keluarga. Hal ini disebabkan pendapatan nelayan yang hanya bergantung pada hasil tangkapan ikan. Apabila hasil tangkapan ikan yang semakin banyak maka dapat dipastikan bahwa kebutuhan pangan tercukupi dan sisa pendapatan dapat digunakan untuk memenuhi kebutuhan lainnya.

Kemampuan modal atau penghasilan adalah pendapatan yang diperoleh nelayan dari hasil tangkapan. Pendapatan adalah salah satu faktor yang menyebabkan nelayan tidak dapat mencukupi kebutuhan pangan rumah tangga. Hasil penelitian menunjukkan sebanyak $23(57,5 \%)$ nelayan memiliki pendapatan sekitar Rp. 290.000,00 sampai dengan Rp. 390.000,00 termasuk kategori sedang.

Pendapatan yang diperoleh nelayan berdasarkan dari rata-rata hasil tangkapan ikan di laut.Nelayan akan melaut apabila sedang kondisi cuaca baik apabila tidak pada kondisi cuaca yang baik maka tidak melaut. Hal tersebut dapat mempengaruhi pendapatan nelayan yanghanya bergantung pada hasil tangkapan ikan sehingga dapat mempengaruhi kebutuhan pangan maupun non pangan keluarga nelayan (Widyaningsih, 2015).

Selain pendapatan, jumlah anggota keluarga yang dimiliki akan mempengaruhi pembagian kebutuhan pangan atau non pangan. Jumlah anggota keluarga akan mempengaruhi persediaan makanan, dimana pada rumah tangga yang memiliki jumlah anggota yang kecil maka akan mendapatkan pangan yang cukup (Sari, 2013). Jumlah anggota keluarga adalah salah satu faktor yang dapat menentukan status ketahanan pangan rumah tangga. Jumlah anggota keluarga adalah besar jumlah anggota rumah tangga yang tinggal dalam satu rumah.

Apabila jumlah anggota keluarga semakin besar maka pembagian makanan akan menjadi lebih besar dari pendapatan dibandingkan keluarga yang memiliki jumlah anggota yang lebih kecil (Sari, 2011). Jumlah anggota keluarga nelayan di
Kelurahan Sukolilo Baru sebagian besar termasuk kategori kecil dan sedang. Hal ini menunjukkan bahwa kecukupan pangan untuk keluarga dapat tercukupi karena jumlah anggota keluarga yang tidak banyak.

Kategori jumlah anggota keluarga akan mempengaruhi tingkat konsumsi dan pengeluaran rumah tangga sehingga semakin banyak jumlah anggota keluarga maka semakin meningkat pengeluaran untuk pangan (Lindawati dan Saptanto, 2014). Faktor pengeluaran rumah tangga dapat dipengaruhi oleh pendidikan pada kepala keluarga. Hasil penelitian menunjukkan banyaknya jumlah nelayan yang menempuh pendidikan terakhir adalah 19 orang tamat SD/MI dan 18 orang tamat SMP/MTs. Hal ini menunjukkan tidak ada responden yang tidak pernah menempuh pendidikan. Jika pendidikan di keluarga nelayan meningkat maka keluarga akan lebih pandai dalam memanajemen keuangan sehingga kebutuhan dapat tercukupi (Primayastanto et al., 2013).

Kelurahan Sukolilo Baru merupakan wilayah yang masalah gizi kurang yang masih banyak. Berdasarkan data dari Badan Pusat Statistik Kota Surabaya menunjukkan Kelurahan Sukolilo Baru merupakan wilayah yang memiliki kasus balita gizi kurang di Kecamatan Bulak Kota Surabaya (BPS Kota Surabaya, 2016).

Keluarga nelayan merupakan keluarga yang beresiko rawan pangan sehingga dapat mempengaruhi status gizi balita. Status ketahanan pangan rumah tangga nelayan yang termasuk berpengaruh terhadap status gizi balita. Balita merupakan kelompok anak usia di bawah lima tahun yang sedang mengalami pertumbuhan sehingga membutuhkan zatzat gizi (Arisman, 2004).

Indeks penentuan status gizi pada penelitian ini menggunakan berat badan menurut umur $(\mathrm{BB} / \mathrm{U})$. Berdasarkan hasil data penelitian diperoleh status balita gizi kurang sebanyak 11 orang dan gizi baik sebanyak 29 orang. Kemudian hasil data 
recall $2 \times 24$ jam ditemukan bahwa balita yang memiliki status gizi kurang maka beresiko kekurangan asupan energi. Hal ini sesuai dengan penelitian yang dilakukan oleh Putri (2016) jika konsumsi energi dari makanan tidak tercukupi maka akan terjadi kekurangan asupan energi sehingga mengakibatkan penururnan berat badan.

Pada usia balita dibutuhkan asupan makanan yang lebih besar karena masa pertunbuhan yang cepat. Asupan energi yang rendah pada balita dapat berakibat meningkatnya resiko masalah gizi kurang dibandingkan dengan balita yang mengkonsumsi energi yang cukup (Rahman, 2016).

Hasil Uji statistik yang dilakukan dengan menggunakan uji regresi linier pada variabel dependent dan independent untuk mengetahui hubungan antara energi, karbohidrat, lemak, dan protein dengan status gizi balita BB/U. Variabel dependant adalah status gizi balita sedangkan independant adalah asupan energi, karbohidrat, lemak, dan status ketahanan pangan. Uji dilakukan untuk mengetahui faktor-faktor mana yang dapat mempengaruhi status gizi balita.

Hasil dari uji statistik regresi linier menggunakan metode enter diketahui bahwa asupan energi merupakan faktor yang dapat di lihat Tabel 2 mempengaruhi status gizi balita. Energi dan asupan makronutrien saling terkait dengan status gizi pada individu. Hal ini menunjukkan bahwa zat gizi makronutrien adalah satu yang dapat mempengaruhi status gizi.

Asupan energi dan lemak adalah dua faktor yang dapat mempengaruhi langsung status gizi balita terutama pada indeks berat badan menurut umur $\mathrm{BB} / \mathrm{U}$. Asupan lemak dapat mempengaruhi status gizi balita dilihat dari penimbangan berat badan yang menunjukkan pertambahan pada timbangan dibandingkan sebelum menimbang (Regar, 2014).

Lemak merupakan salah satu bagian dari makronutrien. Pada hasil analisis statistik regresi linier lemak berhubungan dengan status gizi balita. Hal ini dikarenakan lemak termasuk bagian dari energi dan salah satu indikator yang dapat mempengaruhi status gizi pada individu. Hal ini sesuai dengan pernyataan bahwa energi diperoleh dari konsumsi zat gizi makronutrien yaitu karbohidrat, protein, dan lemak (Regar, 2014). Hasil tersebut menunjukkan bahwa asupan energi dan lemak merupakan faktor yang dapat mempengaruhi status gizi balita BB/U. Sebagian besar asupan energi dan lemakpada balita keluarga nelayan termasuk kategori normal.

Asupan zat gizi adalah salah satu faktor langsung yang dapat mempengaruhi status gizi, selain itu status gizi dapat mempengaruhi terjadinya penyakit infeksi sehingga dapat mengganggu penyerapan zat gizi dan menurunkan nafsu makan (UNICEF, 2013). Berdasarkan hasil uji tabulasi silang menunjukkan sebanyak 25 balita yang mengalami defisit asupan energi dan lemak. Hasil uji menunjukkan bahwa orang memiliki kekurangan asupan energi maka beresiko terkena gizi kurang.

Berdasarkan hasil penelitian Burhani (2015) status gizi balita di keluarga nelayan sebanyak 19 dari 21 balita memiliki status gizi normal dan lainnya kategori kurus. Hal ini menunjukkan balita keluarga nelayan sebagian besar memiliki status gizi normal.

Sejalan dengan teori asupan energi bertujuan untuk mempertahankan hidup, menunjang pertumbuhan dan melakukan aktivitas fisik. Kekurangan energi dapat berakibat berat badan turun (Putri, 2016). Asupan energi sangat menunjang untuk tumbuh kembang anak pada usia 25-60 bulan. Pada usia tersebut balita mengalami pertumbuhan yang cepat.

Selain itu dilakukan uji hubungan antara status ketahanan pangan dengan asupan energi dan lemak. Hasil menunjukkan tidak ada hubungan antara status ketahanan pangan rumah tangga dengan asupan energi dan lemak.

Ketahanan pangan bukan merupakan faktor penyebab kurangnya asupan energi dan lemak. Pada penelitian 
Rohaedi (2016) menunjukkan ketahanan pangan rumah tangga mempunyai hubungan dengan status gizi balita. Salah satu indikator ketersediaan makanan untuk memenuhi kebutuhan pangan sangat mempengaruhi status gizi anak.

Hal tersebut menunjukkan bahwa makanan yang dikonsumsi oleh balita dapat mempengaruhi asupan energi dan lemak sehingga menentukan status gizi balita. Pada penelitian ini menggunakan empat indikator ketahanan pangan rumah tangga sedangkan status gizi balita dapat dilihat dari ketersediaan pangan saja. Status ketahanan pangan rumah tangga tidak mempengaruhi langsung terhadap status gizi pada balita. Hal ini dikarenakan merupakan faktor tidak langsung dari status gizi balita.

\section{SIMPULAN}

Berdasarkan hasil penelitian di atas terdapat hubungan antara asupan energi dan lemak dengan status gizi balita sedangkan status ketahanan pangan rumah tangga tidak berhubungan. Hal ini disebabkan asupan energi dan lemak adalah faktor langsung yang dapat mempengaruhi status gizi balita $\mathrm{BB} / \mathrm{U}$.

Oleh karena itu diperlukan kesediaan pangan rumah tangga yang cukup sehingga dapat memenuhi kebutuhan balita. Selain itu perlu adanya peningkatan ketahanan pangan rumah tangga nelayan sehingga terjadinya peningkatan ketersediaan pangan pada kelaurga.

\section{DAFTAR PUSTAKA}

Arisman. 2004. Gizi dalam Daur Kehidupan. Gizi Anak. Jakarta : Penerbit Buku Kedokteran EGC, hal 56-8

Badan Pusat Statistik, 2016. Kecamatan Bulak dalam Angka 2016. Badan Pusat Statistik: Surabaya
Burhani, P.A., Oenzil, F. dan Revilla, G., 2016. Hubungan Tingkat Pengetahuan Ibu dan Tingkat Ekonomi Keluarga Nelayan dengan Status Gizi Balita di Kelurahan Air Tawar Barat Kota Padang. Jurnal Kesehatan Andalas, 5(3).

Kementerian Kesehatan Republik Indonesia. 2013. Riset Kesehatan Dasar. Jakarta: Lembaga Penerbitan Badan Litbangkes

Kementrian Kesehatan Republik Indonesia, 2011. Keputusan Menteri Kesehatan Republik Indonesia Nomor: 1995. MENKES/SK/XII/2010 Tentang Standar Antropometri Penilaian Status Gizi Anak, Jakarta: Kemenkes RI, hlm 1-24

Lindawati, L. and Saptanto, S., 2014. Analisis Tingkat Kemiskinan dan Ketahanan Pangan Berdasarkan Tingkat Pengeluaran Konsumsi pada Rumah Tangga Pembudidaya Ikan (Studi Kasus Di Desa Sumur Gintung, Kabupaten Subang, Jawa Barat). Jurnal Sosial Ekonomi Kelautan dan Perikanan, 9(2).

Muflikhati, I., Hartoyo, U.S., Fahrudin, A. dan Puspitawati, 2010. Kondisi Sosial Ekonomi dan Tingkat Kesejahteraan Keluarga: Kasus di Wilayah Pesisir Jawa Barat. Jurnal Ilmu Keluarga dan Konsumen, 3(1).

Ningsih, M. and Damayanti, Y., 2013. Faktor-Faktor yang Mempengaruhi Pola Konsumsi Pangan dan Gizi Rumah Tangga Nelayan Kecamatan Tungkal Ilir Kabupaten Tanjung Jabung Barat. Jurnal Sosio Ekonomika Bisnis. ISSN.

Primyastanto, M., Efani, A., Soemarno, S. and Muhammad, S., 2013. Faktor Yang Berpengaruh Terhadap Pendapatan Dan Pengeluaran Nelayan Payang Jurung Di Selat Madura. WACANA, Jurnal Sosial dan Humaniora, 16(1). 
Putri, W.W., Sakung, J.M. and Suleiman, R., 2016. Hubungan Tingkat Konsumsi Energi dan Protein dengan Status Gizi Anak Balita di Wilayah Kerja Puskesmas Talise Kecamatan Mantikulore Kota Palu. PROMOTIF: Jurnal Kesehatan Masyarakat, 6(2)

Rachman, H.P.S., 2016. Aksesibilitas Pangan: Faktor Kunci Pencapaian Ketahanan Pangan di Indonesia. JURNAL PANGAN, 19(2).

Regar, E. and Sekartini, R., 2014. Hubungan Kecukupan Asupan Energi dan Makronutrien dengan Status Gizi Anak Usia 5-7 Tahun di Kelurahan Kampung Melayu, Jakarta Timur Tahun 2012. eJournal Kedokteran Indonesia.

Rohaedi, S., Julia, M. and Gunawan, I.M.A., 2016. Tingkat ketahanan pangan rumah tangga dengan status gizi balita di daerah rawan pangan Kabupaten Indramayu. Jurnal Gizi dan Dietetik Indonesia (Indonesian Journal of Nutrition and Dietetics), 2(2).

Saliem, H.P. dan Ariani, M., 2016, August. Ketahanan pangan, konsep, pengukuran dan strategi. In Forum penelitian Agro Ekonomi (Vol. 20, No. 1).

Sari, A.K., 2011, Faktor yang berhubungan dengan ketahanan pangan rumah tangga pada masyarakat nelayan di Kelurahan Sukolilo Kecamatan Bulak Kota Surabaya. Skripsi. Universitas Airlangga.

Sari, A.K., dan Andrias, D.R., 2013, Faktor sosial ekonomi yang berhubungan dengan ketahanan pangan rumah tangga nelayan perkotaan di Surabaya, Media Gizi Indonesia. Vol. 9, No. 1 Januari-Juni 2013.

Sukandar, D., Khomsan, A., Hadi, R., Anwar, F. danEddy, S., 2006. Studi Ketahanan Pangan pada Rumah Tangga Miskin dan Tidak Miskin. Gizi Indonesia, 1(29).

Sukiyono, K., I. Cahyadinata, dan Sriyoto, 2008. Status Wanita dan Ketahanan Pangan Rumah Tangga Nelayan dan Petani Padi di Kabupaten Muko-Muko Provinsi Bengkulu Jurnal Argo Ekonomi, 26(20).

Tajerin, T., Sastrawidjaja, S. and Yusuf, R., 2011. Tingkat Kesejahteraan Dan Ketahanan Pangan Rumahtangga Nelayan Miskin: Studi Kasus di Kelurahan Marunda Baru, DKI Jakarta dan Desa Tanjung Pasir, Banten. Jurnal Sosial Ekonomi Kelautan dan Perikanan, 6(1).

UNICEF, 2013. Improving Child Nutrition. UNICEF : World Bank Publication

Widyaningsih, E. and Muflikhati, I., 2015. Alokasi Pengeluaran dan Tingkat Kesejahteraan Keluarga Pada Keluarga Nelayan Bagan. Jurnal Ilmu Keluarga dan Konsumen, $8(3)$.

Wong, DL dan Whaley, L. 2008. Buku Ajar Keperawatan Pediatrik. Jakarta:EGC

Yuliana, P., Zakaria, W.A. and Adawiyah, R., 2013. Ketahanan pangan rumah tangga nelayan di Kecamatan Teluk Betung Selatan Kota Bandar Lampung. Jurnal IlmuIlmuAgribisnis,1(2) 